\title{
Cardiomyopathy and Cell Therapy: Ejection Fraction Improvement and Cardiac Muscle Mass Increasing, after a Year of Bone Marrow Stem Cells Transplantation, by Magnetic Resonance Image
}

\author{
Oswaldo Tadeu Greco ${ }^{1}$, Idiberto José Zotarelli Filho ${ }^{2 *}$, Marilanda Ferreira Bellini ${ }^{3}$, Aldemir Bilaqui ${ }^{2}$, Artur Soares Souza Junior ${ }^{3}$, Milton
} Artur Ruiz ${ }^{1}$, Ana Carolina de Abreu${ }^{1}$, José Luiz Balthazar Jacob² and Adriana Barbosa Santos ${ }^{3}$

${ }^{1}$ Greco - Cardiology, Arrhythmia and Pacemaker of São José do Rio Preto, SP, Brazil

${ }^{2}$ Institute of Cardiovascular Diseases - IMC - Rua Castelo D'Agua 3030 - São José do Rio Preto, SP, Brazil 15015-210

${ }^{3}$ State University of São Paulo - IBILCE-UNESP, Rua Cristovão Colombo 2265, São José do Rio Preto SP Brazil $15054-000$.

\begin{abstract}
The idiopathic dilated cardiomyopathy (IDC) is one of the major public health problems in the western world. Patients with IDC in functional class IV (New York Health Association - NYHA), even after therapeutic optimization, have high mortality. Stem cell therapy has emerged as a potential therapeutic option for cell death-related heart diseases and several positive effects were assigned to cell therapy in cardiomyopathy. The aim of this study was identify short-term result of cell transplantation in idiopathic dilated cardiomyopathy patients (IDC) who were treated by transplantation of autologous bone marrow mononuclear cells (BMMC). Intracoronary injections of autologous BMMC were performed in eight patients with severe ventricle dysfunction (mean of left ventricle ejection fraction LEVF $=20.03 \%$ ), cardiac mass muscle around $156.2 \mathrm{~g}$ and NYHA between III and IV grades, other 8 IDC patients received placebo. The IDCs were followed - up for one and two years, by magnetic resonance imaging (MRI). The results after one year showed significant improvement in LVEF (mean=181.4) and muscle mass increasing (mean=181.4 g), after two years the LVEF continued improving, reaching a mean of $32.69 \%$ and the cardiac muscle mass kept stable (mean=179.4 g). Excepted for one patient, all the other had improvement in the NYHA functional class. The placebo group did not show any improvement. We believe that BMMC implant may be a beneficial therapeutic option for IDC patients.
\end{abstract}

Keywords: Cardiomyopathy; Bone marrow mononuclear cells transplantation; Left ventricle ejection fraction; Cardiac muscle mass; Magnetic resonance image

\section{Introduction}

Cardiovascular disease is one of the major public health problems in the western world. Costs of hospitalization amount to more than 10 billion U.S. dollars annually, quality of life is poor, and thousands of lives are lost every year $[1,2]$. In Brazil, it is estimated that $2 \%$ of the population are affected by dilated cardiomyopathy [3] and the cardiovascular mortality rate, in 2004 , was 286 people per 100,000 inhabitants [2,3-8].

Dilated cardiomyopathy is a disease without effective therapeutic options in addition to cardiac transplantation [8-14]. Unfortunately, organ rates are low and most of the patients on transplant waiting list died before receiving a new heart [15-20]. Therefore, a therapy capable of improving cardiac function and more accessible to the population is of great interest [21].

In order to cure heart failure, some revolutionary treatment approaches were proposed. Tremendous excitement and controversy have seen in the fields of stem cell biology and cardiac regeneration [22]. Studies in ischemic heart disease demonstrated that stem cells obtained from various sources, including bone marrow, can contribute indirectly to cardiac regeneration [23-26], and indicated the potential use of stem cell therapy in other cardiomyopathies $[27,28]$.

Several positive effects were assigned to cell therapy in cardiomyopathy, for instance: improvement of left volume ejection fraction (LVEF), decreasing end-diastolic and systolic volumes, myogenesis and angiogenesis, after treatment [28-30]. Stem cell therapy has emerged as a potential therapeutic option for cell death- related heart diseases [31,32]. Preclinical and a number of early phase human studies suggested that cell therapy may augment perfusion and increase myocardial contractility, furthermore, the clinical efficacy of cell therapy remains to be proven [33].

Imaging allows for in vivo tracking of cells and can provide a better understanding in the evaluation of the functional effects of cell-based therapies $[33,34]$. Among these are direct labeling of cells with superparamagnetic agents, radionuclide, and the use of reporter genes for imaging of transplanted cells. Magnetic resonance imaging (MRI) is the best suited to meet such broad objective thanks to its resolution and clinical applicability [35]. The use of non-invasive imaging modalities in pre clinical cell therapy studies revealed key aspects of cell biology that will not be observed by other approaches excepted for histological analysis [36,37].

The aim of this study is to identify short-term result of cell transplantation in idiopathic dilated cardiomyopathy patients (IDC)

*Corresponding author: Idiberto José Zotarelli Filho, Institute of Cardiovascular Diseases - IMC - Rua Castelo D’Agua 3030 - São José do Rio Preto SP, Brazil 15015210, Tel: +55(17) 3203-4039; +55(17) 8166-6537; E-mail: m.zotarelli@gmail.com

Received December 03, 2013; Accepted December 21, 2013; Published December 23, 2013

Citation: Greco OT, Filho IJZ, Bellini MF, Bilaqui A, Souza AS Junior, et al. (2013) Cardiomyopathy and Cell Therapy: Ejection Fraction Improvement and Cardiac Muscle Mass Increasing, after a Year of Bone Marrow Stem Cells Transplantation, by Magnetic Resonance Image. J Stem Cell Res Ther S6: 008. doi:10.4172/21577633.S6-008

Copyright: $\odot 2013$ Greco OT, et al. This is an open-access article distributed under the terms of the Creative Commons Attribution License, which permits unrestricted use, distribution, and reproduction in any medium, provided the original author and source are credited. 

and Cardiac Muscle Mass Increasing, after a Year of Bone Marrow Stem Cells Transplantation, by Magnetic Resonance Image. J Stem Cell Res Ther S6: 008. doi:10.4172/2157-7633.S6-008

Page 2 of 5

who were treated by intracoronary transplantation of autologous bone marrow mononuclear cells (BMMC) and compare these results with the placebo (PL) group, by magnetic resonance imaging [33-38].

\section{Materials and Methods}

\section{Materials}

The materials used were trypan blue (Sigma Aldrich, St. Louis, MO, USA), Kit monoclonal antibody CD34 (+), CD34(-), CD 133 (+) and CD 133(-) (BD Biosciences, South America, USA), Kit SEPAX (Biosafe America, Inc.1225 North Loop West, Suite 120, Houston, TX 77008, USA), Flow Cytometry (BD Accuri C6 ${ }^{\text {tw }}$, BD Biosciences, South America, USA). As the density gradient Ficoll-Hypaque was used (Amershan Biosciences, Piscataway, NJ, USA).

\section{Methods}

Experimental design - patients: The study was blinded, randomized and performed at 16 patients diagnosed with idiopathic dilated cardiomyopathy (IDC) at Instituto de Moléstias Cardiovasculares (IMC). Bone marrow mononuclear cell (BMMC) injection was performed in 8 and 8 patients received placebo, at the period between 2005 and 2008. From 16 IDC patients, 12 were male, 4 were female and the mean age was 51.8 years (range: $44-62$ years). Following the functional classification of New York Health Association (NYHA), 10 IDC patients was grade III and 6 was grade IV. The study was approved by Brazilian National Research Ethics Committee (CONEP) (Registration \#: 15342).

The Randomized Assesment of Digoxin on Inhibitors of Angiotensin-Converting Enzyme (RADIANCE) trial found that discontinuing digoxin in patients with low ejection fraction and HF resulted in worsening HF, Current American Heart Assaociation/ American College of Cardiology guidelines classify digoxin use as IIA in patients with current or prior symptoms of HF and reduced left ventricular ejection to decrease hospitalizations for HF.

B-Blockers should be maintained in this hemodynamically stable patient (a Class I indication) because there is no evidence that routinely discontinuing $\beta$-blockers in this setting is beneficial. Patients such as this usually respond well to intravenous loop diuretics (avoiding the absorption issues of oral diuretics in the setting of intestinal edema), with improved renal function as preload is optimized. In patients who are true refractory to diuretics, intravenous nitroglycerine or ultrafiltration can be helpful (Class IIa) (1).

Bone marrow aspiration, isolation of mononuclear cells and cell injection: Before the arrival and manipulating bone marrow sample, it was "check list" materials and reagents required for handling Kit (SEPAX) and bone marrow, such as syringes, needles, $70 \%$ ethanol, gas, human albumin, ficoll and serum. Called up the equipment SEPAX, at least thirty minutes prior to stabilization of electric current. Sterilized room and laminar flow hood with UV light for fifteen minutes. The Kit was manipulated inside the laminar flow hood. The first step to manipulation of the kit was to examine whether all three "taps "were in the position "T". The second step was to close all clamps. The third step was to inject $100 \mathrm{~mL}$ of Ficoll purse specific washing. The fourth step was to discard $62.5 \mathrm{~mL}$ serum bottle and inject the same volume of albumin and connect the bottle right output Kit. The fifth step is to connect the empty bag (for storing the mononuclear cell layer) and the sixth step in the Kit was connected the bag with the bone marrow. For handling the SEPAX was necessary to follow the instructions of the standard protocol for operating the machine in the category of "separation by ficoll." After mounting, the verification was made of three settings: sample volume $(60 \mathrm{~mL})$, number of washes (two washes for $500 \mathrm{~mL}$ serum). After this, the "enter" checked the Kit after checking Kit, opened up all the clamps. Soon after, the software asked to do the pumping purse bone marrow and then tightened "up" twice to adjust the trajectory of the spinal cord to close the entrance. Thereafter, if pressed "enter" to start the process. First, the Ficoll was aspirated into the tube. Then, the marrow was slowly aspirated into the tube on top of the Ficoll. It started spinning and then the fraction of erythrocytes and granulocytes was discarded and mononuclear ficoll layer was aspirated and washed with saline. After one hour the process ends and the mononuclear cell layer was available for quantifying $C D$ $34(+)$ and CD $133(+)$, after obtaining the pellet by centrifugation [28]. The final suspension of bone marrow mononuclear cells contained $3.0 \times 10^{8}$ totals cells (being $5.0 \times 10^{6} \mathrm{CD} 34+$ cells, $2.5 \times 10^{6} \mathrm{CD} 133+$ cells and others cells as monocytes) was injected intracoronary in the affected area. The placebo group received intracoronary injection of saline plus autologous serum of the patient solution, to ensure that the study was double-blind, keeping the color of the injected solutions. Before every injection, the catheter was positioned perpendicular to the endocardium with excellent loop stability and the extension of the needle had to induce a premature ventricle contraction.

Magnetic Resonance Imaging (MRI): Magnetic resonance imaging has become a key surrogate end point to demonstrate efficacy in early phases, small-sized studied. MRI can provide detailed morphologic and functional information and therefore, seems ideally suited to integrate efficacy assessments with the capability for cell tracking [16]. MRI studies were performed using a 1.5-Tesla (GE Medical System, Milwaukee, WI, USA) with 8 channels cardiac array and vector electrocardiographic gating. Two experienced observers, blinded to all clinical data, analyzed the images. Previously validated software was used to determine parameters of global systolic function (Advantage Workstation - AW Volume Share 2 (AW 4.4), Report Card 4.0, GE Medical Imaging System, and Milwaukee, WI, USA).

\section{Statistical Analysis}

The preliminary evaluation of data was performed based on Descriptive statistics and univariate analysis. The nonparametric Friedman test was applied to assess the time of assessment effect (T0, $\mathrm{T} 1$ and T2) was significant. Nonparametric comparisons post hoc Friedman test was also used. The level of significance was set as $\mathrm{p}<0.05$. The statistical analysis was carried out with the statistical software MINITAB 15.1.

\section{Results}

The left ventricle ejection fraction (LVEF) descriptive statistics can be observed in Table 1 and these results were calculated based on measurements made both before cell therapy (T0), after one year of therapy (T1) and after two years (T2). By the statistical univariate analysis, BMMC treated patients reacted positively to the infusion, considering that the average values of LVEF increased from $22.64 \%$ to $29.75 \%$ at the $\mathrm{T} 0$ to $\mathrm{T} 1$, reaching $32.69 \%$ at the $\mathrm{T} 2$.

The analysis of extreme values (minimum and maximum) shown that there was a positive evolution on LVEF, which is most significant in the first year. We can also observe important data variability, after a year and two years of therapy. While at the T0 the LVEF varied between 7.4 to $44.1 \%$, after one year (T1) the percentage increased to 
Citation: Greco OT, Filho IJZ, Bellini MF, Bilaqui A, Souza AS Junior, et al. (2013) Cardiomyopathy and Cell Therapy: Ejection Fraction Improvement and Cardiac Muscle Mass Increasing, after a Year of Bone Marrow Stem Cells Transplantation, by Magnetic Resonance Image. J Stem Cell Res Ther S6: 008. doi:10.4172/2157-7633.S6-008

Page 3 of 5

$18.8 \%$ of the minimum and $58.9 \%$ of the maximum LVEF value (Figure 1). In the second year, patients were maintained between 20 and $56.5 \%$. By the data dispersion and the number of patients, LVEF median estimates were considered more reliable than the means.

Some patients had remarkable improvement in the first year of treatment, increasing LVEF in $16.1 \%$. For others, the increase was in second year and also those who had remained stable or showed a slight reduction of $4.2 \%$ in the LVEF within the period. Overall the trend is growth in the first year and a lower increase from first to second year (Figure 2). The placebo group did not show any improvement, neither on LEVF $(p=0.429)$ nor for cardiac mass $(p=0.438)$. The data of this group is also on Table 1.

Table 1 also presents the results of univariate analysis performed for the cardiac mass $(\mathrm{CM})$, where we can verify that most patients remained at levels near the values unchanged at both times, the first year and the second year of treatment. Baseline the mean weight was $177.2 \mathrm{~g}$ with a standard deviation of $87.8 \mathrm{~g}$. The values ranged from 57.1 to $387.3 \mathrm{~g}$ for 8 analyzed IDC patients, half of them had initial $\mathrm{CM}$ at least $161.8 \mathrm{~g}$. One year after the infusion of stem cells, the average rose to $189.6 \mathrm{~g}$, standard deviation fell to $53.1 \mathrm{~g}$ and the values of CM were included a narrower band (121.6 to $290.7 \mathrm{~g}$ ). The median increased in proportion of the average, and reached $174.2 \mathrm{~g}$. After $163.1 \mathrm{~g}$, both estimates similar to those initials. The standard deviation (SD) has remained in the first year $(\mathrm{SD}=51.9 \mathrm{~g})$, as well as range of variation, which was between 130 and $290.7 \mathrm{~g}$. The results in Table 1 indicate differences obtained by the Friedman test $(\mathrm{P}=0.031)$ and the significance found by post hoc test $(\mathrm{P}=0.021)$, which indicates changes in cardiac mass after one year, suggesting a CM increase (Figure 1). For the period of two years there is no significant difference $(\mathrm{P}=0.141)$. There is an increasing trend of CM after 1 year, but with the passing of another year, there is a reduction to initial levels (Figure 3).

The patients had a good evolution in the post-implant with improvement of NYHA functional class. Only one patient kept his NYHA grade (III), 50\% of IDC patient's improved one class in NYHA grade (IV to III, and III to II) and 37.5\% improved two classes, changing from IV to II, or III to I grades.

The comparisons between placebo and BMMC groups no showed statistically significant difference for LVEF ( $\mathrm{p}$-value $=0.1307$ ) but an increasing on cardiac mass was observed $(p$-value $=0.0005)$ between BMMC and PL therapy on the both times ( $\mathrm{p}$-value $<0.001)$.

\section{Discussion}

The reparative effects of cardiac tissue may either be due to paracrine effect caused by stem cells in the bone marrow, stimulating the process of "homing " of macrophages, neutrophils, monocytes, stem cells and telocytes, and by differentiation processes of infused cells. In the case of a paracrine effect, the first highlighted are macrophages can be induced by stem cells to produce nitrogen oxide (NO), it is important for tissue regeneration. The second highlight is the telocytes - interstitial cells of Cajal - which play an important role in intercellular communication $[18,19]$. In the case of cell differentiation, the small fraction of mesenchymal stem cells may have differentiated into cardiomyocytes, and hematopoietic stem cells may have contributed to the cardiac tissue angiogenesis process and may also have transdiferenciated in cardiomyocytes. Furthermore, in adult heart, stem cells there are at rest, but can rapidly proliferate when stimulated with growth factors released by the infused stem cells and macrophages. This is solid evidence that the heart is in a continuous process of growth, cell death and renewal [3].

In preclinical studies, the effects of cell therapy were analyzed in experimental models of infection with Trypanosoma cruzi in mice with chronic Chagas cardiomyopathy. It was observed that infusion of bone marrow stem cells in mice have reduced heart
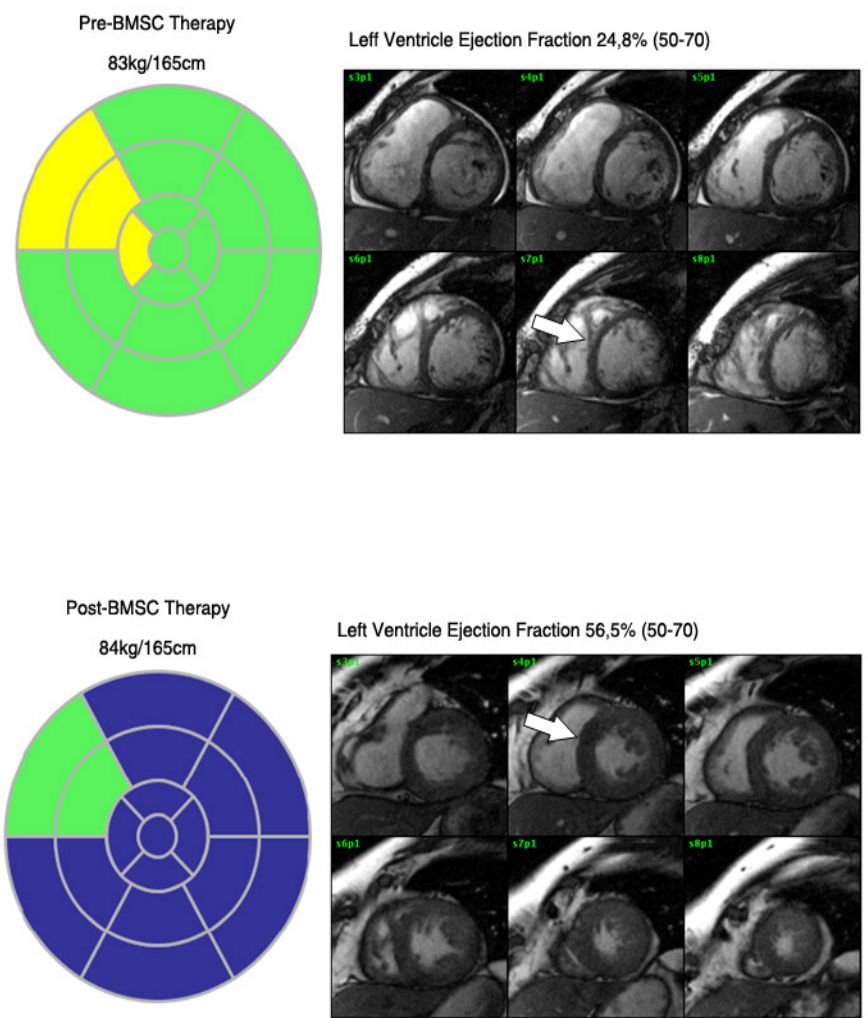

Figure 1: Evolution on left ventricle ejection fraction and increasing cardiac mass muscle before, after a year and two years of therapy, by resonance magnetic image.

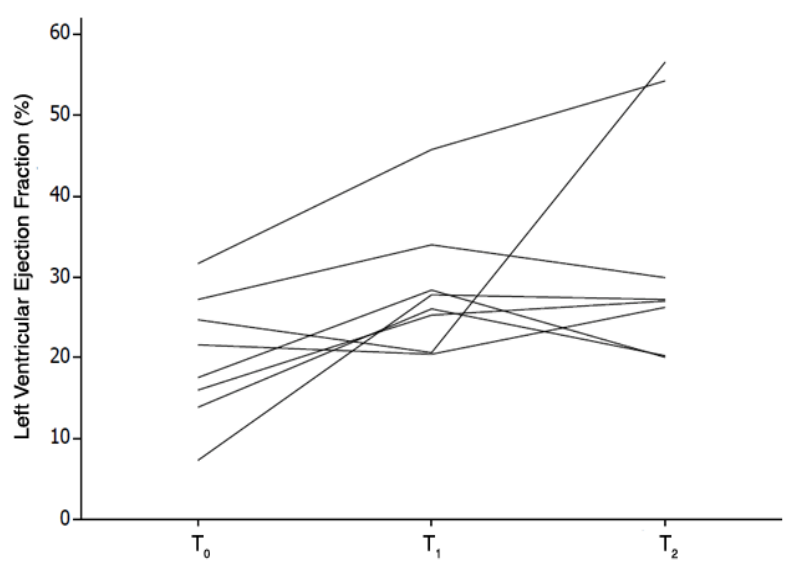

Figure 2: Left ventricle ejection fraction (\%) improvement of eight idiopathic dilated cardiomyiopathy patients, before (T0), one year (T1) and two years (T2) after cellular therapy, by magnetic resonance imaging. 


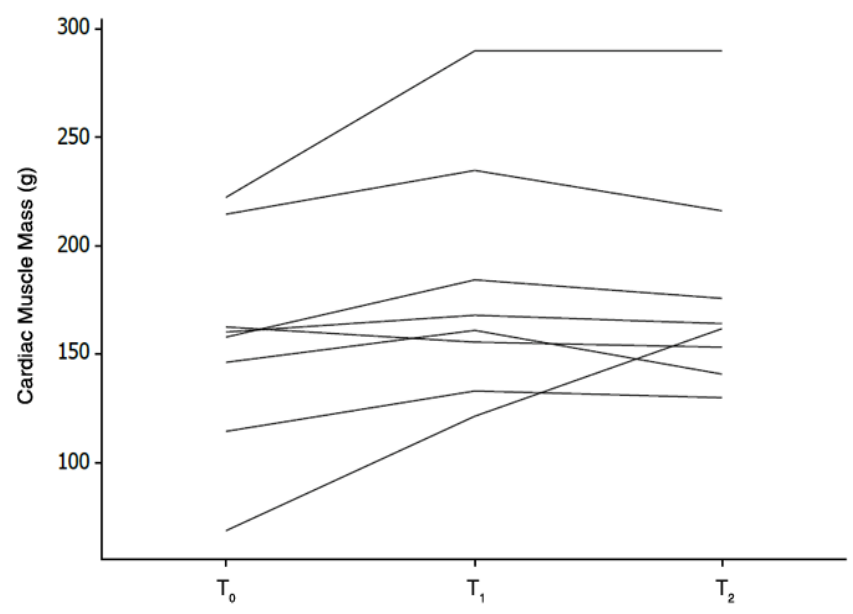

Figure 3: Cardiac muscle mass $(\mathrm{g})$ improvement of eight idiopathic dilated cardiomyiopathy patients, before (T0), one year (T1) and two years (T2) after cellular therapy, by magnetic resonance imaging.

inflammation and fibrosis of the gain area in the healthy heart, after six months of treatment [4]. In addition, another study analyzed the direct administration of mesenchymal stem cells from bone marrow in the left ventricular wall in co-culture with skeletal myoblasts for 14 days, showing improvement in LEVF $23 \%$ to $34 \%$ of the heart, contraction of volume reduction systolic and diastolic blood pressure and the presence of myogenesis and angiogenesis after treatment [13]. In another preclinical model of left ventricular dysfunction after myocardial infarction in pigs subjected to infusion of bone marrow stem cells resulted in the formation of new cardiac tissue, with a relative reduction of infarct size and hemodynamic improvement. The evidence of efficacy without obvious safety concerns in 8 week followup motivated studies in human patients post- myocardial infarction and chronic ischemic cardiomyopathy [22].

In one case report was observed after infusion of stem cells from bone marrow by intracoronary technique, a significant number of these cells were attracted and retained in specific areas of the heart with myocardial fibrosis [15]. During a period of four years of study together, myoblasts were successfully transplanted in patients with ischemic cardiomyopathy, echocardiography, we measured an average increase in LVEF from $28 \%$ to $35 \%$ at 1 year and $36 \%$ at 2 years [6]. The improvement in LVEF from $25 \%$ to $36 \%$ was also observed in patients with post-infarction heart failure undergoing therapy bone marrow cells [20].

The data from this study corroborated the results of the literature, since it showed the positive trend in LVEF by MRI, of $22.64 \%$ to $29.75 \%$ to $32.69 \%$ after the first and second year Infusion bone marrow stem cells in dilated cardiomyopathy, respectively, and statistically significant when compared with the standard active drug treatment. These results were also similar to those found for chronic myocardial ischemia during a multicenter, randomized trial [21]. In 2007, 17 studies are available that assessed the changes in LV function after cell therapy, most of them indicated small improvements in LVEF (ranging from $2.9 \%$ to $9.3 \%$ ) [16], we found an improvement in LEVF $7.11 \%$ after the first year and $10.05 \%$ after the second year of cell therapy, probably the literature described.
Using a combination of electrophysiological and imaging techniques it is concluded that electrically active cardiomyocytes derived from human embryonic stem cells are able to actively pacing at rest, the recipient ventricular cardiomyocytes in vitro and in vivo ventricular myocardium, suggesting an alternative or complementary method for correction of defects in cardiac impulse generation, such as pacemakers based on cells [7]. In experimental models, the infarct size after - myocardium and remained constant in the placebo showed a trend towards reduction in low dose, high dose therapy MSC reduced infarct size from $18.2( \pm 0.9 \%)$ to $14.4( \pm 1.0 \%)$ with (p-value $=0.02)$, left ventricular mass. In addition, both treatments of low and high dose increased regional contractility and myocardial blood flow in both infarct and border areas [19]. Saw an increase in muscle mass 156.2 to 181.4 during the first year but decreased to 179.4 in the second year after cell therapy, indicating that the ideal for the regeneration of muscle mass period is the first year post treatment and these results are statistically significant when compared with placebo. Another group showed a significant improvement in cardiac function and volume, resolution of healing and increased wall thickness for severe ischemic dilated cardiomyopathy patients with cardiac magnetic resonance imaging at 6 months of infusion of bone marrow stem cells in relation to baseline [23].

The analysis of the ejection fraction of the right ventricle indicates an improvement of heart function six months after the stem cell transplant. Similarly, we observed an increase in walking time and race test [14]. Patients undergoing cell therapy in this study also showed an improvement in functional class, except for one patient who remained NYHA class III, the other patients showed good recovery post- implant, where $50 \%$ of IDC patients reduced one NYHA class grade (IV to III and III to II) and $37.5 \%$ showed an improvement of two classes, from IV to II or III to I.

\section{Conclusion}

Considering the results obtained by magnetic resonance imaging, we can consider that trends of improvement in ejection fraction and increased cardiac muscle mass in the first year after cell therapy, but these clinical parameters are less pronounced between the first and second year. However the idiopathic dilated cardiomyopathy patients had a good clinical response to the implant of autologous stem-cells. Thus, we conclude that the infusion of bone marrow mononuclear cells has greater therapeutic efficiency in dilated cardiomyopathies.

\section{Acknowledgements}

The work was financially supported by the HMC Hospital / BMI of São José do Rio Preto - Brazil. We appreciate the support of Duke University (Durham, NC, USA) in the field of research and statistical studies and also appreciate the support of the Life Group (Brazil), Biosafe (Switzerland, EC) and Celartia (Ohio, USA). The authors are grateful to Dra. Adriana Barbosa Santos for statistical help.

\section{Disclosure of Potential Conflicts of Interest}

The authors declare that they have no conflicts of interests.

\section{Copyright License Statement}

The authors warrant the originality of the material in the above manuscript. Each author transfers exclusively to the Publisher all of his or her rights in the material (whether in written or electronic form) in the above manuscript as now or hereafter protected by the Copyright Laws of the United States of America and the Universal Copyright Laws, for all purposes and for the duration of the copyright, including all subsidiary rights. 
Citation: Greco OT, Filho IJZ, Bellini MF, Bilaqui A, Souza AS Junior, et al. (2013) Cardiomyopathy and Cell Therapy: Ejection Fraction Improvement and Cardiac Muscle Mass Increasing, after a Year of Bone Marrow Stem Cells Transplantation, by Magnetic Resonance Image. J Stem Cell Res Ther S6: 008. doi:10.4172/2157-7633.S6-008

\section{References}

1. Orlic D, Kajstura J, Chimenti S, Bodine DM, Leri A, et al. (2001) Transplanted adult bone marrow cells repair myocardial infarcts in mice. Ann $N$ Y Acad Sci 938: 221-229 discussion 229-230.

2. Orlic D, Kajstura J, Chimenti S, Limana F, Jakoniuk I, et al. (2001) Mobilized bone marrow cells repair the infarcted heart, improving function and survival. Proc Natl Acad Sci U S A 98: 10344-10349.

3. Nadal-Ginard B (2001) Inducción de nuevos cardiomiocitos en el corazón adulto:futuro de la regeneración miocárdica como alternativa al trasplante. Rev Esp Cardiol 54: 543-550.

4. Soares MBP, Lima RS, Rocha LL, Takyia CM, Pontes-de-Carvalho L, et al. (2004) Transplanted bone marrow cells repair heart tissue and reduce myocarditis in chronic chagasic mice. Am J Pathology 164: 441-447.

5. Vilas-Boas F, Feitosa GF, Soares MB, Pinho-Filho JA, Mota A, et al. (2004) Bone marrow cell transplantation to the myocardium of a patient with heart failure due to Chagas' disease. Arq Bras Cardiol 82: 185-187.

6. Dib N, McCarthy P, Campbell A, Pagani FD, Wright S, et al. (2005) Feasibility and safety of autologous myoblast transplantation in patients with ischemic cardiomyopathy. Cell Trnsplant 14: 11-19.

7. Xue T, Co HC, Akar FG, Tsang SY, Jones SP, et al. (2005) Functional Integration of Electrically Active Cardiac Derivatives From Genetically Engineered Human Embryonic Stem Cells With Quiescent Recipient Ventricular Cardiomyocytes: Insights Into the Development of Cell-Based Pacemakers. Circulation 111: 1120.

8. Barbash IM, Leor J (2006) Myocardial regeneration by adult stem cells. Isr Med Assoc J 8: 283-287.

9. EntrezProgrammingUtilities. http://www.who.int/whosis/whostat/EN_WHS09 Full.pdf.

10. EntrezProgrammingUtilities.http://adam.sertaoggi.com.br/encyclopedia/ency/ article/000168.htm.

11. EntrezProgrammingUtilities.http://www.fiocruz.br/chagas/cgi/cgilua.exe/sys/ start.htm?sid=161.

12. Leri A, Kajstura J, Anversa $P$ (2006) Células da Medula Óssea e Reparo Cardíaco. Arq Bras Cardiol 87: 71-22.

13. Guarita-Souza LC, Carvalho KA, Woitowicz V, Rebelatto C, Senegaglia A, et al (2006) Simultaneous Autologous Transplantation of Cocultured Mesenchymal Stem Cells and Skeletal Myoblasts Improves Ventricular Function in a Murine Model of Chagas Disease. Circulation 114: I-120-I-124

14. Vilas-Boas F, Feitosa GF, Soares MB, Mota A, Pinho-Filho JA, et al. (2006) Early Results of Bone Marrow Cell Transplantation to the Myocardium of Patients with Heart Failure due to Chagas Disease. Arq Bras Cardiol 87: 159166.

15. Jacob J, Salis FV, Ruiz MA, Greco OT (2007) Labeled Stem Cells Transplantation to the Myocardium of a Patient with Chagas' Disease. Arq Bras Cardiol 89: e10-e11.

16. Beeres SL, Bengel FM, Bartunek J, Atsma DE, Hill JM, et al. (2007) Role of imaging in cardiac stem cell therapy. J Am Coll Cardiol 49: 1137-1148.

17. Gepstein L (2008) Experimental molecular and stem cell therapies in cardiac electrophysiology. Ann N Y Acad Sci 1123: 224-231.

18. Quevedo HC, Hatzistergos KE, Oskouei BN, Feigenbaum GS, Rodriguez JE, et al. (2009) Allogeneic mesenchymal stem cells restore cardiac function in chronic ischemic cardiomyopathy via trilineage differentiating capacity. Proc Natl Acad Sci U S A 106: 14022-14027.

19. Schuleri KH, Feigenbaum GS, Centola M, Weiss ES, Zimmet JM, et al. (2009) Autologous mesenchymal stem cells produce reverse remodelling in chronic ischaemic cardiomyopathy. Eur Heart J 30: 2722-2732.
20. Van Ramshorst J, Atsma DE, Beeres SL, Mollema SA, Ajmone Marsan N, et al. (2009) Effect of intramyocardial bone marrow cell injection on left ventricular dyssynchrony and global strain. Heart 95: 119-124

21. Van Ramshorst J, Bax JJ, Beeres SL, Dibbets-Schneider P, Roes SD, et al. (2009) Intramyocardial Bone Marrow Cell Injection for Chronic Myocardial Ischemia. A Randomized Controlled Trial. JAMA 301: 1997-2004.

22. Johnston PV, Sasano T, Mills K, Evers R, Lee ST, et al. (2009) Engraftment differentiation, and functional benefits of autologous cardiosphere-derived cells in porcine ischemic cardiomyopathy. Circulation 120: 1075-1083.

23. Chin SP, Poey AC, Wong CY, Chang SK, Teh W, et al. (2010) Cryopreserved mesenchymal stromal cell treatment is safe and feasible for severe dilated ischemic cardiomyopathy. Cytotherapy 12: 31-37.

24. Uba-Surma E, Klich I, Greco N, Laughlin M, Ratajczak J, et al. (2010) Optimization of isolation and further characterization of umbilical-cord-bloodderived very small embryonic/epiblast-like stem cells (VSELs). Eur J Haematol 84: $34-46$.

25. Mendez-Ferrer S, Michurina TV, Ferraro F, Mazloom AR, Macarthur BD, et al. (2010) Mesenchymal and haematopoietic stem cells form a unique bone marrow niche. Nature 466: 829-834.

26. Baldomero H, Gratwohl M, Gratwohl A, Tichelli A, Niederwieser D, et al. (2011) The EBMT activity survey 2009: trends over the past 5 years. Bone Marrow Transplant 46: 485-501.

27. Kränkel N, Spinetti G, Amadesi S, Madeddu P (2011) Targeting stem cell niches and trafficking for cardiovascular therapy. Pharmacol Ther 129: 62-81.

28. To LB, Levesque JP, Herbert KE (2011) How I treat patients who mobilize hematopoietic stem cells poorly. Blood 118: 4530-4540.

29. Greco OT, Fernando VS, Milton AR (2011) An idiopathic myocardiopathy control patient submitted to autologous stem cells implant-case report. Journal of Medicine and Medical Sciences 2: 618-621.

30. Ratajczak MZ, Kim CH, Abdel-Latif A, Schneider G, Kucia M, et al. (2012) A novel perspective on stem cell homing and mobilization: review on bioactive lipids as potent chemoattractants and cationic peptides as underappreciated modulators of responsiveness to SDF-1 gradients. Leukemia 26: 63-72.

31. Rankin SM (2012) Chemokines and adult bone marrow stem cells. Immunol Lett 145: 147-254.

32. $\mathrm{Xu} \mathrm{H}$, Yi BA, Wu H, Bock $\mathrm{C}$, Gu H, et al. (2012) Highly eficiente derivation of ventricular cardiomyocytes from induced pluripotent stem cells with a distinct epigenetic signature. Cell Res 22: 142-154.

33. Bhartiya D, Shaikh A, Nagvenkar P, Kasiviswanathan S, Pethe $P$, et al. (2012) Very small embryonic-like stem cells with maximum regenerative potential get discarded during cord blood banking and bone marrow processing for autologous stem cell therapy. Stem Cells Dev 21: 1-6.

34. Schneider CA, Rasband WS, Eliceiri KW (2012) NIH Image to Image J: 25 years of image analysis. Nat Methods 9: 671-675.

35. Heider A, Danova-Alt R, Egger D, Cross M, Alt R (2013) Murine and human very small embryonic-like cells: a perspective. Cytometry A 83: 72-75.

36. Alvarez-Gonzalez C, Duggleby R, Vagaska B, Querol S, Gomez SG, et al. (2013) Cord Blood Lin- CD45- Embryonic-Like Stem Cells Are a Heterogeneous Population That Lack Self-Renewal Capacity mail.

37. Alvarez P, Carrillo E, Vélez C, Hita-Contreras F, Martínez-Amat A, et al. (2013) Regulatory Systems in Bone Marrow for Hematopoietic Stem/Progenitor Cells Mobilization and Homing. Biomed Res Int 2013: 312656.

38. Zotarelli IJF, Abreu AC, Greco OT, Bilaqui A, Kassis EN, et al. (2013) Measurement and feasibility of hematopoietic stem cell was greater for equipment in closed system. IJDR 3-7. 